\title{
ІНСТИТУЦІЙНІ ПЕРЕТВОРЕННЯ В СИСТЕМІ ДЕРЖАВНОГО УПРАВЛІННЯ ЗЕМЕЛЬНИМИ РЕСУРСАМИ
}

${ }^{1}$ Сохнич А. Я. д. е. н., професор,

${ }^{2}$ Смолярчук М. В. к. е. н., дочент,

${ }^{2}$ Сохнич О. А. к. е.н.

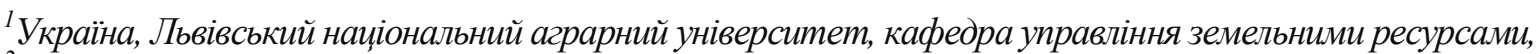

${ }^{2}$ Украӥна, Держаудитслужба Украйни, головний державний аудитор

\section{DOI: https://doi.org/10.31435/rsglobal_ijite/01062018/5665}

\section{ARTICLE INFO}

Received 06 April 2018

Accepted 11 May 2018

Published 01 June 2018

\section{KEYWORDS}

state administration,

land resources,

public debt,

foreign investment,

digital technology,

unemployment,

economic management

\begin{abstract}
Today one of the problems is the fact that a significant part of the management team of different levels of government management is not well acquainted with the real state of the economy of the country and the necessity of its urgent reforming, which objectively impedes the transition to a new, more progressive, model of management of the country. Thus, a wellgrounded judgment those radical changes in human resources policy have long been on time.

The scientific and theoretical aspects of the infrastructure restructuring of Ukraine's economy, its structural elements and institutional ways of state management of land resources are researched in the article. General tendencies of decreasing of economic indicators in the most significant spheres of economy of the country, including the land one, are investigated on the basis of the continuation of the destructive influence of crisis phenomena due to the global financial crisis.

It is pointed out the importance of a radical change of the vector of the investment policy of the state from the passive and expectation one to the dynamically active one, which will give the opportunity to obtain modern technologies that are extremely necessary today, taking into account the miserable state of science in the state
\end{abstract}

Вступ. Вже багато років питання домінування деструктивних процесів в економіці України ставиться, як особливо важливе. Слід зазначити, що для досягнення позитивних змін в економічному розвитку України необхідно чітко і однозначно визначити напрями радикальної модернізації окремих галузей на основі ринкових засад. Важливим позитивом у цих реформах $€$ те, що головною причиною гальмування національної економіки визначена застаріла постсоціалістична система управління національною економікою та іiі підсистема управління земельними ресурсами. Зрозуміло, що оскільки підсистема управління земельними ресурсами $\epsilon$ підпорядкованою загально-державній системі управління всією економікою країни, то вона кооптувала в себе всі тї недоліки. Наразі всі питання, які розглядаються стосовно загальнодержавних механізмів управління економікою, автоматично стосуються і механізмів управління земельними ресурсами в межах країни, що свідчить про ії актуальність та вагомість.

Виклад основного матеріалу. Оскільки Україна фактично знаходиться в центрі Європи, то Європейський Союз, як стратегічний партнер нашої країни приділяє достатньо уваги політичним, економічним та соціальним реформам і надає посильну фінансову та консультативну допомогу. Через це і не дивно, що економічну ситуацію в країні сьогодні найкраще оцінюють відомі закордонні вчені, які особливо наголошують, що втрачені можливості українського народу лежать не в площині матеріального виробництва чи фінансових потоків, а у відповідній системі управління народним господарством, яка вже не відповідає реаліям часу. Вітчизняні економісти давно обходять цей чинник стороною, оцінюючи та досліджуючи вже тільки катастрофічні наслідки в більшості непрофесійного керування країною.

Зміна системи управління економікою держави та її земельними ресурсами, зокрема в умовах росту економіки в короткі терміни є безперечно революцією, як в економічній, так і в соціальній сферах. 
Нами проведено загальний аналіз стану об’єктів державного управління земельними ресурсами в рамках державної системи управління національною економікою [9, 12, 16, 22], зокрема, досліджено загальні тенденції падіння економічних показників у найбільш значущих сферах економіки країни, у тому числі в земельній, на тлі продовження деструктивного впливу кризових явищ через світову фінансову кризу.

На рисунку 1. представлений механізм державного управління земельними ресурсами (локальний рівень).

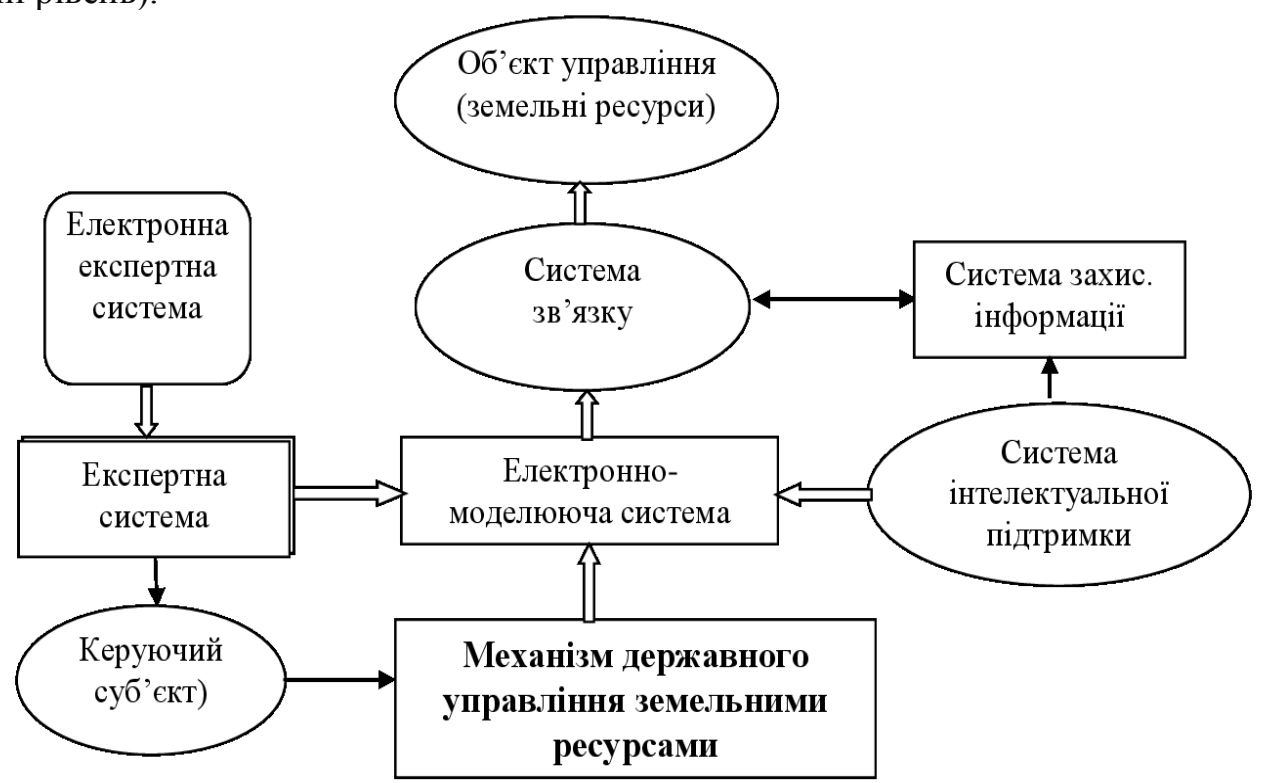

Рис. 1. Механізм держсавного управління земельними ресурсами (локальний рівень)

Система управління земельними ресурсами не є чітко окресленою, оскільки є включеною в загальнодержавну систему управління й тісно пов'язана з усіма сферами економіки, адже немає таких сфер, які б прямо чи дотично не стосувались питань земельних ресурсів.

У результаті наукового пошуку виявлено, що гальмування ринкових процесів у всіх без винятку сферах економіки спричинено неефективною системою управління національною економікою.

Морально й фізично застаріла система управління земельними ресурсами, що грунтується на організаційних принципах XIX ст., просто не справляється із завданнями, які продукує сучасна багатовекторна економіка $[2,4,8,18]$.

У часи комп'ютерного буму у виробництві товарів і послуг, у системі управління національною економікою активно використовують ручну працю. Система оперативного прийняття рішень найвищим законодавчим органом у державі ВРУ $є$ вкрай повільною, що об'єктивно стримує розвиток національної економіки.

Загальновідомо, що там, де управління функціонує в ручному режимі, виникає системна корупція. Враховуючи той факт, що державні інститути впливають на всі сфери життєдіяльності людей та функціонування виробництва товарів і послуг, можна стверджувати, що якість управління є визначальною для зростання національної економіки.

У розвинутих економіках світу $[13,23,24]$ іноземні інвестиції становлять не більше ніж $20 \%$, а $80 \%$ - це національні інвестиції. Але в нашій державі такі величезні фінансові ризики та нестабільна законодавча база, що найбільші українські інвестиції шукають своєї легалізації за кордоном. А ці кошти вкрай потрібні всередині країни для створення нових робочих місць. Як видно (рис. 2) населення України постійно знижується і тепер економіка має проблеми із робочою силою на виробництві.

На жаль економіка нашої країни не була, і досі не є готовою до економічно правильного споживання наданих кредитів. Ці кредитні ресурси потрібно було направити на модернізацію реального сектору економіки, натомість ці гроші «накачувались»у приватні банки, а потім через їх заплановане банкрутство розкрадались і переводились в закордонні банки. У підсумку, Україна замість прибутків отримала величезні борги. На жаль, цей механізм розвалу держави діє і донині. Прямі іноземні інвестиції замість росту значно впали (табл. 1; рис. 3 ).

Після виведення за кордон значної частини банківських ресурсів, банки втрачали стабільність через низьку капіталізацію і закривались, а залишки коштів перераховувались у Державний фонд гарантування вкладів. Таким чином, за останні роки сума залишків склала 380 
млн. долл. США, але іï оцінили в 87 млн. долл. США, різниця очевидно була приватизована. Такі маніпуляції у фінансовій сфері завдали значних матеріальних збитків збіднілому населенню.

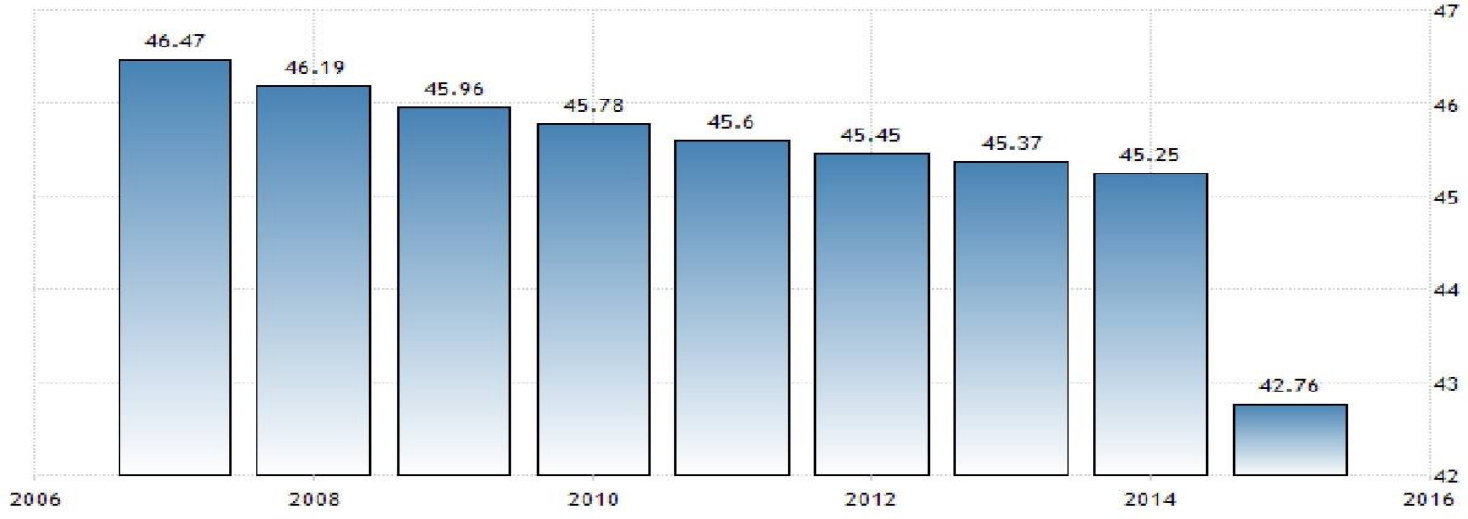

Рис. 2. Населення України, млн. чол.

Таблиця 1. Державний борг України в період 2010 - 2015 pp.

\begin{tabular}{|c|c|c|c|c|c|c|c|}
\hline \multicolumn{4}{|c|}{ Загальний борг } & \multicolumn{2}{c|}{ Зовнішній борг } & \multicolumn{2}{c|}{ Внутрішній борг } \\
\hline $\begin{array}{c}\text { Датрахунку } \\
\text { розрарге }\end{array}$ & $\begin{array}{c}\text { Сума боргу, Відхилення, } \\
\text { млн. грн. } \\
\text { млн. грн. }\end{array}$ & $\begin{array}{c}\text { Відхи- } \\
\text { лення, \% }\end{array}$ & $\begin{array}{c}\text { Сума боргу, } \\
\text { млн. грн. }\end{array}$ & $\begin{array}{c}\text { Відхи- } \\
\text { лення, \% }\end{array}$ & $\begin{array}{c}\text { Сума боргу, } \\
\text { млн. грн. }\end{array}$ & $\begin{array}{c}\text { Відхи- } \\
\text { лення, \% }\end{array}$ \\
\hline на 01.01.2010 & 316884,6 & & & 211751,7 & & 105132,9 & \\
\hline на 01.01.2011 & 432235,4 & $+115350,8$ & $+36,4$ & 276745,6 & $+30,7$ & 155489,8 & $+47,9$ \\
\hline на 01.01.2012 & 473121,6 & $+40886,2$ & $+9,5$ & 299413,9 & $+8,2$ & 173707,7 & $+11,7$ \\
\hline на 01.01.2013 & 515510,6 & $+42388,9$ & $+9,0$ & 308999,8 & $+3,2$ & 206510,7 & $+18,9$ \\
\hline на 01.01.2014 & 584114,1 & $+68603,5$ & $+13,3$ & 300025,4 & $-2,9$ & 284088,7 & $+37,6$ \\
\hline на 01.01.2015 & 1100564,0 & $+516449,9$ & $+88,4$ & 611697,1 & $+103,9$ & 488866,9 & $+72,1$ \\
\hline на 10.09.2015 & 1494891,4 & $+394327,5$ & $+35,8$ & 9764217,1 & $+59,8$ & 518460,4 & $+6,2$ \\
\hline
\end{tabular}

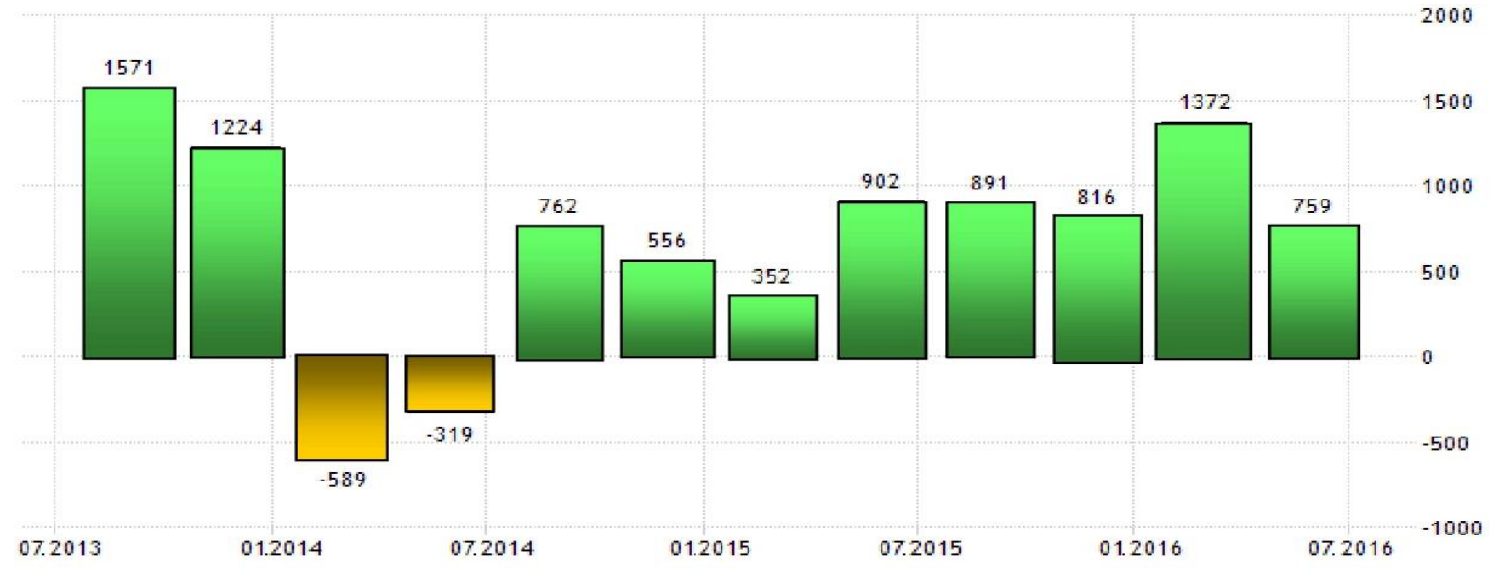

Рис. 3. Прямі іноземні вкладення, млн. дол. США

Нескладні розрахунки закордонних економістів показують, що борги держави наростають такими темпами, що через 2,5-3 роки прийдеться віддати у погашення боргів значну частину родючої сільськогосподарської землі.

Тут важливо зазначити, що у заставу підуть і пайові землі 6,5 млн. селян, якими вони тепер володіють. Зрозуміло, що без бою віддавати іноземним банкам свої землі ніхто не збирається, і прогнозувати розвиток подій тепер ніхто не береться. Але, враховуючи світовий досвід, можна зазначити, що Україна тут на жаль не одинока, можуть початись громадянські заворушення та акти громадянської непокори, що точно призведе до значних економічних втрат.

Безробітних громадян, які вміють використовувати зброю, вже сьогодні більше 5 млн., так що воювати за будь-що є кому і це вносить соціальну нестабільність в наше суспільство. Такі загрози не спонукають закордонних інвесторів вкладати довготривалі інвестиції в нашу економіку.

Все керівництво країни активно працює над залученням все нових і нових кредитів, 3 яких вони потім отримують величезні статки. Складається враження, що отримання кредитів іє головною ціллю керівництва держави. 
Щоб не відповідати за розбалансований житлово-комунальний сектор та більше 3000 державних підприємств, які керівництву тільки знижують рейтинги, вони вирішили їх приватизувати, 3 передачею, як правило, у свої руки та передати відповідальність за зруйнований житлово-комунальний сектор на місцеві органи влади, під приводом запровадження децентралізації та примарної передачі прав на місця.

Вже як закономірність: прийнятий головний кошторис країни вже через декілька місяців потребує серйозних доопрацювань, і бюджет автоматично переходить на ручне керування, яке породжує зловживання у фінансовій сфері. Держава відповідальна за всі сфери життєдіяльності населення (рис. 4).

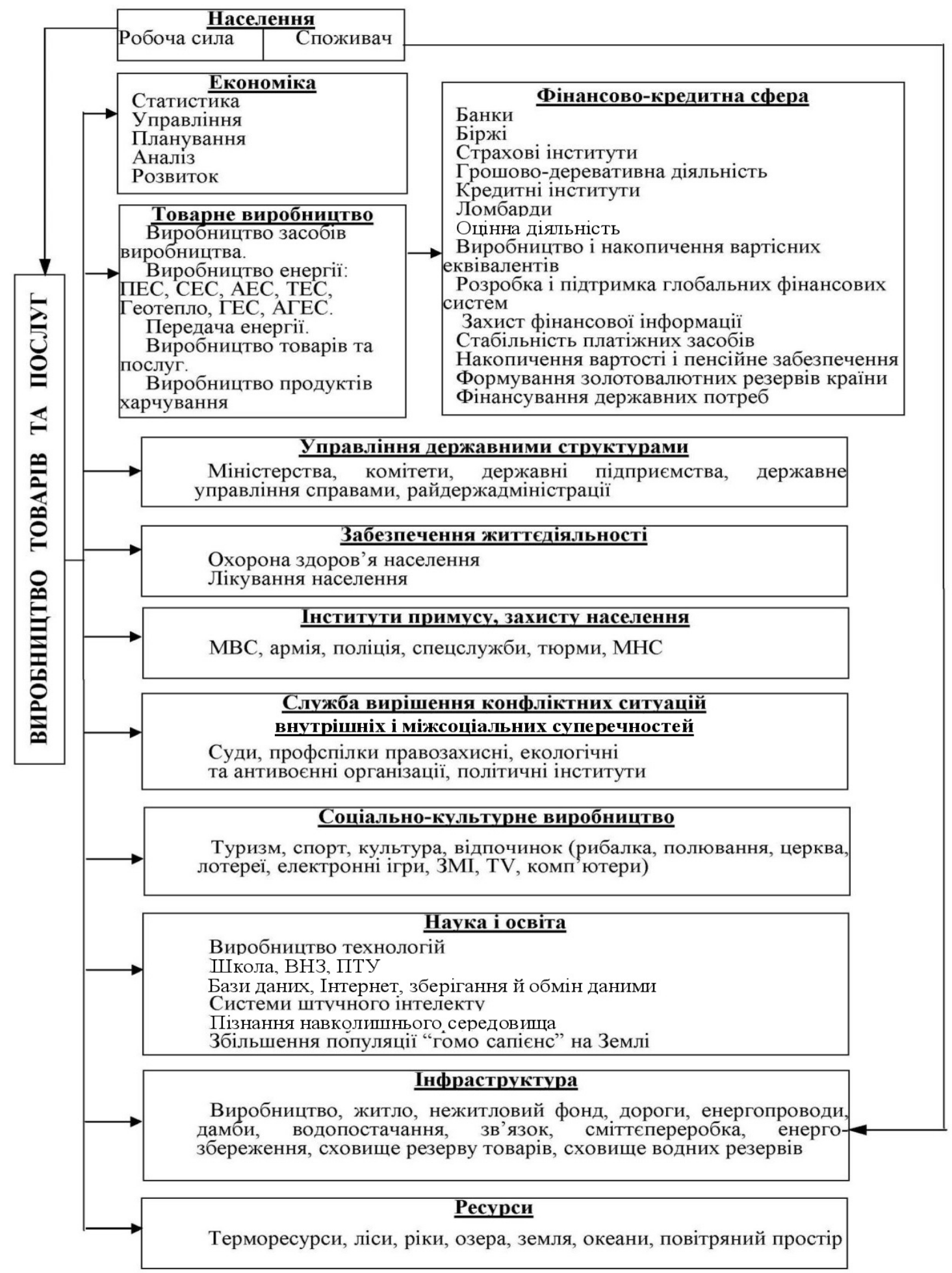

Рис. 4. Основні функиї сучасної держави в системі управління національною економікою 
Засновник американської технологічної компанії «Sales - force.cjm» М. Беніофф, вважає, що 3 входженням у нову цифрову еру XXI століття потрібна принципово нова Конституція, яка по новому визначить права, відповідальність і головне перспективи розвитку суспільства з врахуванням можливостей штучного інтелекту біомашинних технологій і нових екологічних вимог.

Він заявляє те, з чим в принципі можна погодитись: «Ми повинні об’єднатися разом 3 урядом, політиками, бізнесом, наукою та лідерами загальносуспільної думки, щоб включитися у роботу незалежно від місця проживання над створенням і запровадженням комплексу технічних, політичних, етичних i особистих норм та правил 3 метою створення нової інтернаціональної Конституції цифрової ери XXI століття» [21].

Для прикладу, слід зазначити, що останнім часом керівництво США виділяє 3 федерального бюджету тільки 4 \% для проведення наукових досліджень у сферах новітніх цифрових технологій та розвитку на їх базі динамічного суспільного середовища. Для порівняння у 1967 році ця цифра складала 10,7 \%.

Важливі сфери економічного розвитку сучасного світу такі, як чиста енергетика, інфекційні хвороби, репродукція біологічних штаммів, кібербезпека, антитерористичний захист отримують недостатньо фінансування від Конгресу США. Зокрема, вчені [14, 20] погоджуються 3 необхідністю розробки принципово нової політики в сфері проведення фундаментальних досліджень для стратегічних розробників, які створюють і впроваджують нове покоління продуктів та послуг. Представники нових технологій зазначають, що засновники компаній i інші бізнес-лідери повинні об'єднатись із своїми акціонерами, робітниками, клієнтами, партнерами та місцевими соціумами і зрозуміти, що ми всі частина однієї великої екосистеми. Такі питання, як глобальні зміни клімату, світове виробництво продуктів та послуг, знаходяться під впливом науки та освіти, які впливають на кожен бізнес.

Багатьом людям не вистачає можливостей отримати якісну освіту - це дуже погано впливає на бізнес. У світі більше 200 млн. безробітних людей - це теж дуже погано для бізнесу».

Рівень безробіття в Україні характеризується такими показниками (рис. 5).

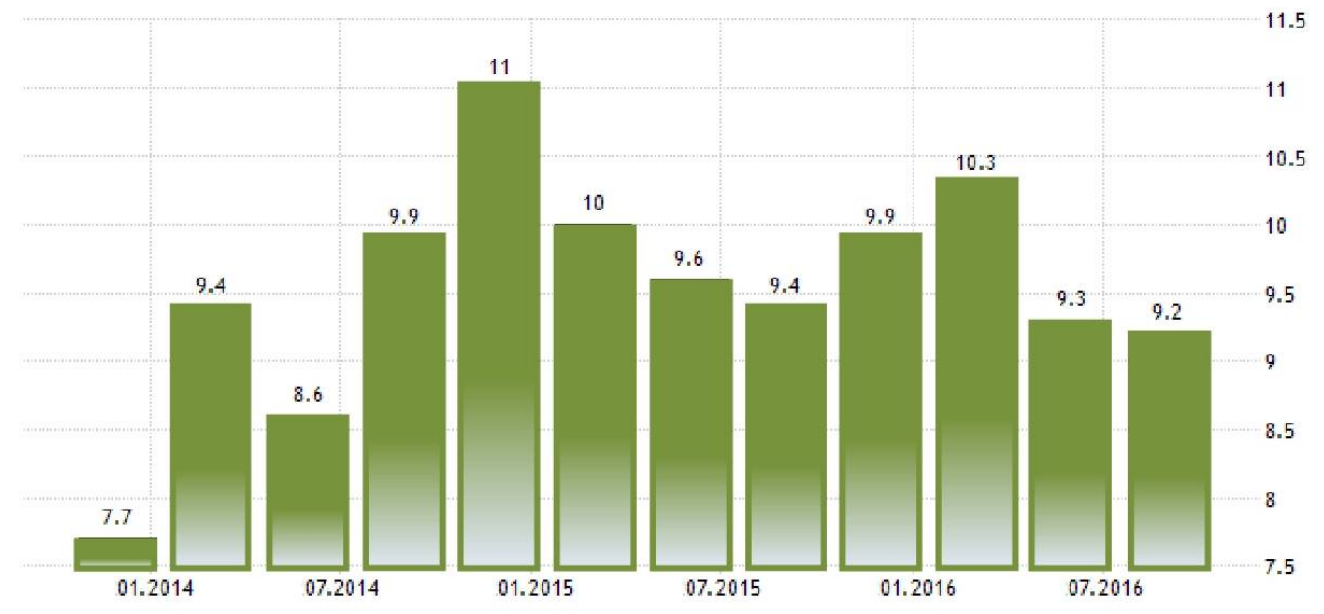

Рис. 5. Рівень безробіття в Україні, \%

Найближчі 15 років мають стати найбільш визначальними в розвитку в усіх сферах комп'ютерних технологій, у тому числі в системах управління всіма сферами виробництва та економікою країн у цілому. За останні 2,5 роки було створено 92 \% всієї інформації в світі. До 2020 року більше 60 млрд. пристроїв буде підключено до Інтернету через мережі 4G та 5G.

Особливо зазначимо, що кількість згенерованої інформації буде подвоюватися кожні 2 роки, а до 2020 року складе сумарно 44 трлн. гігабайт.

На фоні таких стрімких технологічних досягнень державні інституції, їх функції та системи державного управління виглядають абсолютно застарілими.

Якість управління у депресивних країнах, таких як Україна не витримує ніякої критики $[5,6,7,17,19]$. Чиновники ходять на роботу в основному, щоб отримувати пільги, особливі матеріальні блага, але не для того, щоб вирішувати проблеми місцевого соціуму та підвищення ефективності економіки регіонів та країни в цілому. Реформи в царині державної служби управління є вкрай складними через опір самої системи, яка не бажає змін.

Всередині країни накопичились невирішені питання у сфері економіки [1, 3, 10], які потрібно вирішувати в найближчі роки. Щоб вирішити ці питання потрібно проводити не 
децентралізацію, а консолідацію 3 метою уникнення дублювання управлінських рішень стосовно одних і тих же питань і скоротити витрати 3 бюджету на ці цілі. Ось актуальні питання, які має вирішувати синтезована цифрова система управління економікою країни в цілому і земельними ресурсами зокрема.

Коштів на це, як завжди не вистачає і відповідальність за їх вирішення практично ніхто персонально не несе. Вирішення кожного 3 цих стратегічних питань лежить у площині взаємодії в тій чи іншій мірі зі сферою земельних ресурсів, якість управління якими тепер перебуває на початковому етапі. Саме земельні ресурси можуть реально продукувати додану вартість і фінансувати задекларовані керівництвом держави широкомасштабні реформи у всіх сферах економіки країни.

Висновки. Окреслено головну причину занепаду економіки - це некомпетентність головного законодавчого органу держави, який продукує лобістські закони повністю ігноруючи необхідність їх глибокого наукового обгрунтування. Вказано на важливість радикальної зміни вектору інвестиційної політики держави 3 пасивно-вичікувальної на динамічно активну, що дасть можливість отримати сучасні технології які вкрай необхідні сьогодні, зважаючи на жалюгідний стан науки в державі.

Кошти, які залучаються від закордонних кредиторів не передбачають їх використання у перспективних галузях 3 метою гарантування своєчасного поверненню кредитів та отримання прибутку для проведення розширеного виробництва.

\section{ЛІТЕРАТУРА}

1. Аграрний сектор економіки України (стан і перспективи розвитку) / [Присяжнюк М. В., Зубець М. В., Саблук П. Т., Ходаківська О. В. та ін.]; за ред. М. В. Присяжнюка, М. В. Зубця, П. Т. Саблука, В. Я. Месель-Веселяка, М. М. Федорова. - К. : ННЦ IAЕ, 2011. - 1008c.

2. Арчибальд Р. Управление высокотехнологичными программами и проектами / Рассел Д. Арчибальд; Пер. с англ. Мамонтова Е. В.; Под ред. Баженова А. Д., Арефьева А. О. 3-е изд., перераб. и доп. - М. : Компания АйТи, ДМК Пресс, 2004. - 472 с.

3. Бабміндра Д. І. Еколого-економічні засади реформування землекористування в ринкових умовах : автореф. дис. на здобуття наук. ступеня док. екон. наук : спец. 08.08.01 „Економіка природокористування і охорони навколишнього середовища" / Д. І. Бабміндра. - К., 2005. - 26 с.

4. Бавико О.Є. Управління структурною перебудовою економіки в умовах постіндустріальних трансформацій / О. С. Бавико // Ефективна економіка. - Дніпропетровськ : Дніпроп. держ. аграр.-економ. універ., 2014. - С.45-49.

5. Балюк С. А. Управлінню грунтово-земельними ресурсами - державну підтримку / С. А. Балюк, В. В. Медведєв, М. М. Мірошниченко // Вісник аграрної науки. - 2009

6. Білик Ю. Д. Організаційно-економічні та правові аспекти вдосконалення державного управління земельними ресурсами / Ю. Д. Білик // Землевпорядний вісник. - 2003. - №1. - С. 16-18.

7. Богіра М. С. Земельна реформа в Україні: наслідки і перспективи / М. С. Богіра // Землевпорядний вісник. - 2006. - № 4. - С. 35-37.

8. Бойко Л. М. Регулювання земельних відносин у сільському господарстві : монографія / Бойко Л. М. - К. : ННЦ ІАЕ, 2011. - 316 с.

9. Боклаг В.А. Планування використання та охорони земель як складова загальнодержавної системи планування / В.А. Боклаг // Актуальні проблеми державного управління. - 2011. - № 1. - С. 30-34.

10. Бородіна О. М. Підтримка аграрного сектора в системі державного регулювання економіки / О. М. Бородіна, Ю. М. Лопатинський. - Чернівці : ЧНУ, 2009. - 280 с.

11. Горлачук В. В. Наукові основи управління земельними ресурсами. Лекція / Горлачук В. В., В’юн В. В., Сохнич А. Я. - Львів : Укр. технології. - 2002. - 76 с.

12. Данкевич А. Є. Світовий досвід оренди земель / А. Є. Данкевич // Економіка АПК. - 2007. - № 3. - С. 138 - 144.

13. Добряк Д. С. Землеустрій - наукова основа раціонального використання та охорони земельних ресурсів // Добряк Д. С., Мартин А. Г. // Землеустрій і кадастр. - 2006. - № 1. - С 10-16.

14. Ібатуллін Ш. І. Механізми управління земельними відносинами в контексті забезпечення сталого розвитку / Ш. І. Ібатуллін, О. В. Степенко, О. В. Сакаль [та ін.]. - К. : Державна установа «Інститут економіки природокористування та сталого розвитку Національної академії наук України», 2012. - 52 с.

15. Кадикова I. М. Формування ринку землі в умовах ринкової трансформації : автореф. дис. на здобуття наук. ступеня канд. екон. наук : спец. 08.00.01 «Економічна теорія» / I. М. Кадикова. - Х., 2008. - 20 с. - укр. 
16. Кошкалда I. В. Земельні відносини в аграрному секторі економіки України: [монографія] / І. В. Кошкалда. - Х. : Гриф, 2012. - 352 с.

17. Наукові і методичні основи управління земельними ресурсами : [монографія] / за ред. д. е. н. А. Я. Сохнича. - Львів : Укр. технології, 2007. - 237 с.

18. Пахомова Н. В. Структурные преобразования в условиях формирования «зеленой» экономики: вызовы для государства и бизнеса / Н.В.Пахомова, К.К. Рихтер, Г.Б. Малишков // Проблеми современной экономики. - 2012. - № 3(43). - С. 7-15.

19. «Сконцентрируйтесь на тех $20 \%$, от которых зависит $80 \%$ дела» [Електронний pecypc]. - Режим доступу: https://www.vedomosti.ru/technology/ characters/2017/09/11/733316skontsentriruites

20. Третяк А. М. Земельні ресурси України та їх використання / А. М. Третяк, Д. І. Бамбідра. - К. : ЦЗРУ, 2003. - 143 с.

21. The publications of the United Nations on economic and social affairs - UNDESA. UNpublication, 2005. - № E.04. - II.C.1.

22. Wille Joachim. Menschheit braucht bald zwei Planeten / Joachim Wille // Frankfurter Rundschau. - 2012. - 15 may. - P. 3. 